\title{
Peganum harmala seed extract can prevent HSV-1 replication in vitro
}

\author{
Kiani S.J., Shamsi Shahrabadi M.*, Ataei A., Sajjadi N. \\ Department of Virology, Iran University of Medical Sciences, Tehran, IRAN.
}

\begin{abstract}
Peganum harmala L. (Zygophylaceae) has been used in a variety of practical applications in medical science. Our objective in the current study was to determine the effects of the seed extract on Herpes simplex virus type 1 (HSV-1) replication in Vero cells. Different concentrations $(100,500,571,667,800$ and $1000 \mu \mathrm{g} / \mathrm{ml})$ of the extract were examined. Experiments were carried out using Vero cells. P.harmala seed extract was found to be non-toxic to Vero cells up to a concentration of $667 \mu \mathrm{g} / \mathrm{ml}$. The antiviral activity of nontoxic concentration against HSV-1 was tested. The replication of HSV-1 was inhibited, indicating that the P.harmala L. extract contains an anti-HSV-1 substance.
\end{abstract}

Keywords: Peganum harmala L. GVero cells OTCID50 6Cytotoxicity

\section{Introduction}

$\mathrm{H}$ erpes simplex viruses (HSV) are ubiquitous agents which cause a variety of diseases ranging in severity from mild to severe, and in certain cases, these may even become life threatenings, especially in immunocompromised patients. After primary infection, HSV persists in the host for the lifetime. HSV infection is thus considered lifelong infection. Nucleoside analogues such as acyclovir (ACV), pencyclovir, are the only approved drugs for the treatment of HSV infections. However, the widespread use of nucleoside based drugs has led to the emergence of resistance in HSV especially among immunocom-promised patients (1).

Herbal remedies used in the traditional folk medicine provide an interesting and still largely unexplored source for the creation a development of potentially new drugs for chemo-therapy which might help to overcome the growing problem of resistance and also the toxicity of the currently available commercial antibiotics. The traditional medicinal methods, especially the use of medicinal plants, still play a vital role to cover the basic health needs in the developing countries. Therefore, it is of great interest to carry out a screening of these plants in order to validate their use in folk medicine and to reveal the active principle by isolation and characterization of their constituents

\footnotetext{
*Corresponding Auther: M.Shamsi Shahrabadi; Department of Virology, Iran University of Medical Sciences, Tehran, Iran; Post Code: 144561313.

Email: Mshahrabadi@hotmail.com
}

(2). A great number of medicinal plants are being used to treat microbial infections, particularly in the rural areas of Iran where the traditional folk medicine remains a major source to cure minor ailments.

The Peganum harmala L. (Syrian rue) is a wildgrowing flowering plant belonging to the Zygophylaceae family and is found abundantly in Middle East and North Africa (3). From ancient times, it has been claimed to be an important medicinal plant. Its seeds are known to possess hypothermic and hallucinogenic properties $(4,5)$. It has been used traditionally as an emmen-agogue and an abortifacient agent in the Middle East and North Africa (6). There are several reports in the literature indicating a great variety of pharmacological activities for Peganum harmala $\mathrm{L}$ such as anti-bacterial, antifungal and monoamine oxidase (MOA)-inhibition (7). It has also been known to interact with $\alpha 2$-Adrenoceptor subtypes (8) and have hallucination potency and be effective in the treatment of dermatosis (9), hypothermic (10) and cancer (11).

Thus the aim of this study was to elucidate the possible mechanism underlying the action of alkaloid extract of peganum harmala seeds on herpes simplex virus type 1 replication in cell culture.

\section{Material \& Methods}

\section{Plant material}

The plant material was collected from Tabriz, Iran on July 2007. Five grams of dried and powdered seeds of peganum harmala fruits was macerated 


\section{Peganum harmala seed extract can prevent HSV-1 replication}

four times with $50 \mathrm{ml}$ methanol at $5^{\circ} \mathbb{C}$ in water bath for $1 \mathrm{~h}$. The extracts were combined and evaporated to dryness. The residue was dissolved in $1 \mathrm{~N} \mathrm{HCL}$ at concentration of $2 \%$ then filtered. The filtrate was extracted two times with $20 \mathrm{ml}$ petroleum ether. The aqueous acid layer was basified $(\mathrm{pH} 10)$ with $1 \mathrm{~N} \mathrm{NaOH}$ and extracted four times with $50 \mathrm{ml}$ chloroform. The chloroform layer was combined and evaporated to dryness, and then the residue was dissolved in $25 \mathrm{ml}$ methanol. The solution of alkaloid extract was passed through $0.45 \mu \mathrm{m}$ filter and stored at $4^{\circ} \mathrm{C}$ refrigerator for further use.

\section{Cell culture \& Virus}

Vero cells (African green monkey kidney cells) were cultured as monolayers in DMEM supplemented with $10 \%$ heat-inactivated fetal bovine serum (FBS), $100 \mathrm{IU} / \mathrm{ml}$ penicillin, and 100 $\mu \mathrm{g} / \mathrm{ml}$ streptomycin. The cells were maintained at $37^{\circ} \mathrm{C}$ in a humidified atmosphere with $5 \% \mathrm{CO}_{2}$ and were subcultured twice a week.

HSV-1 was isolated from patients, and identified by monoclonal anti-HSV-1 antibodies. Viruses were propagated in Vero cells and quantified in terms of the $50 \%$ tissue culture infective dose (TCID50) by endpoint dilution, with the infectious titer determined by the method of Reed and Muench (12) and stored as small aliquots at $-70{ }^{\circ} \mathrm{C}$ until use.

\section{Cytotoxicity assay}

In order to test the effects of the extract on Vero cells, $5 \times 10^{4}$ cells (in $1 \mathrm{ml}$ DMEM, supplemented with $10 \%$ FBS) were seeded into each well of microplates, cultured for $6 \mathrm{~h}$ at $37^{\circ} \mathrm{C}$, and cells were allowed to grow for additional $48 \mathrm{~h}$ in the presence of increasing amounts of extract (100, $500,571,667,800$ and $1000 \mu \mathrm{g} / \mathrm{ml}$ ). The cytotoxicity of extracts was determined on a conventional hemocytometer using the trypan blue exclusion method (13).

The highest noncytocidal (on Vero cells) concentration of plant extract was determined to be $667 \mu \mathrm{g} / \mathrm{ml}$. Therefore, the 667 $\mu \mathrm{g} / \mathrm{ml}$ concentration was used for the determination of antiviral activities.

\section{Virus yield inhibition assay}

Nontoxic concentration of test drug was checked for antiviral property by virus yield reduction assay (14) against virus challenge dose of 100 TCID $50 / \mathrm{ml}$. In virus yield assay, reduction in the yield of virus when cells were treated with the plant extract was determined.

\section{Pre-incubation of cell monolayer with extract before virus infection}

The extract was dissolved in serum free DMEM and incubated with semi-confluent cell in 96-well tissue culture plates in mentioned concentration for 2 and $5 \mathrm{~h}$ at $37^{\circ} \mathrm{C}$ and $5 \% \mathrm{CO}_{2}$. After removal of the extract, the cells were washed with phosphatebuffered saline (PBS) and then infected with HSV1 at a multiplicity of infection (MOI) of 0.1. After $1 \mathrm{~h}$ incubation the unad-sorbed virus was removed, the cell monolayer was washed with PBS and further incubated in DMEM with $2 \%$ FBS. Controls consisted of Vero cells untreated alone and Vero cells infected with HSV-1.

\section{Incubation of virus with extract before virus infection}

The assay was performed as described above, with the exception that extract was added together with the virus. Virus stock was mixed with mentioned concentration of extract in equal volume, and used for infecting cells. After an incubation time of $1 \mathrm{~h}$, the solutions containing both extract and virus were removed, the cell monolayer was washed with PBS and further incubated in DMEM with 2\% FBS.

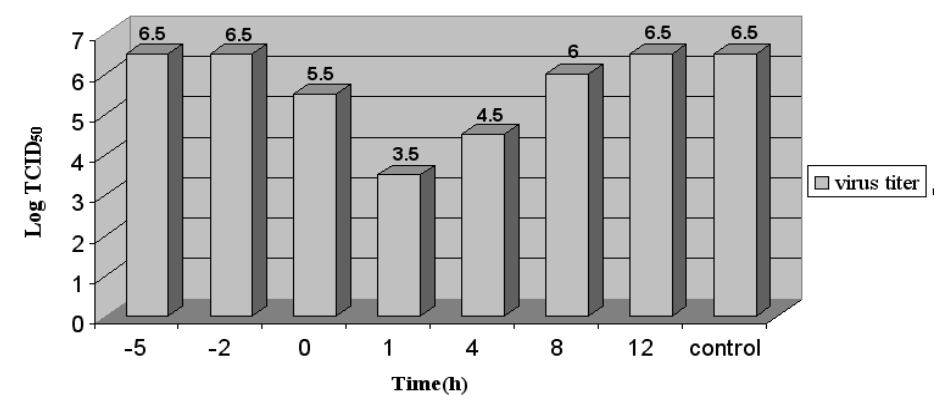

Fig. 1: Effect of the extract pre-, during and post-infection on virus yield in Vero cells. 


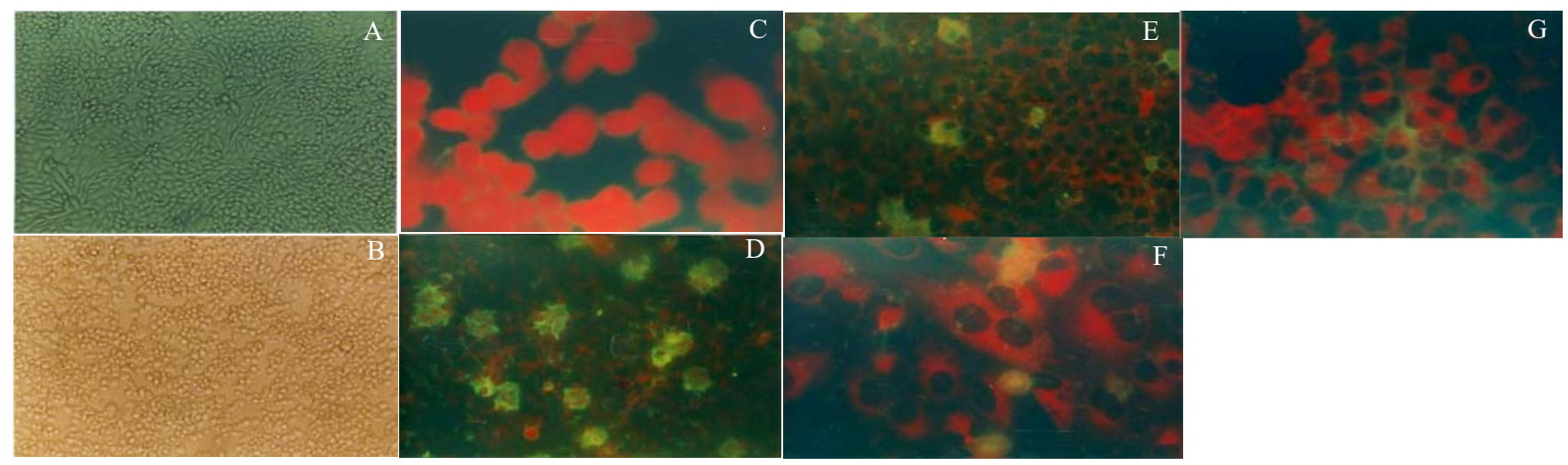

Fig. 2: (A) Monolayer of uninfected Vero cells; (B) HSV-1 infected monolayer of Vero cells; (C) Uninfected monolayer processed for Immunofluorescence[negative control]; (D) HSV-1 infected monolayer processed for Immunofluorescence[positive control]; (E) Infected Vero cells incubated for $16 \mathrm{~h}$ in the presence of $667 \mu \mathrm{g} / \mathrm{ml}$ of the extract in first passage; (F) Infected Vero cells incubated for $16 \mathrm{~h}$ in the presence of $667 \mu \mathrm{g} / \mathrm{ml}$ of the extract in second passage; $(G)$ Infected Vero cells incubated for $16 \mathrm{~h}$ in the presence of $667 \mu \mathrm{g} / \mathrm{ml}$ of the extract in third passage.

\section{Incubation of cell monolayer with extract after virus infection}

The cell monolayer was infected with the virus. After $1 \mathrm{~h}$ incubation the unadsorbed virus was removed, the cell monolayer was washed with PBS and then incubated with mentioned concentr-ation of the extract in DMEM with $2 \%$ FBS after 1, 4, 8, and $12 \mathrm{~h}$ post infections. After $48 \mathrm{~h}$ incubation at 37 ${ }^{\circ} \mathrm{C}$ in presence of $5 \% \mathrm{CO}_{2}$, super-natant was removed and semi-confluent cell monolayer, grown in 96-well plate, was inoculated with 10-fold dilutions of the supernatant for $1 \mathrm{~h}$ at $37{ }^{\circ} \mathrm{C}$. After removal of the inocula, monolayer was washed once with PBS and then incubated in DMEM containing 2\% FBS for $48 \mathrm{~h}$. Virus titer was determined by the endpoint dilution method and expressed as TCID50 according to the ReedMuench formula. The results were expressed as reduction ratio of virus titers by comparison with virus control.

\section{Immunofluorescence}

Confluent Vero cells grown on $13 \mathrm{~mm}$ coverslips were infected with HSV-1 at MOI of 1 TCID50 for $16 \mathrm{~h}$ in the presence of $667 \mu \mathrm{g} / \mathrm{ml}$ of the extract compared to untreated infected cells. The cover slips were removed, washed in PBS and fixed in acetone at $4{ }^{\circ} \mathrm{C}$; then they were stained indirectly with fluoresceine conjugated anti-human IgG using specific viral antiserum. The cover slips were mounted in glycerol buffer and examined in a UV equipped microscope.

\section{Polymerase Chain Reaction}

To determine presence of viral DNA in extracttreated infected cells, DNA was extracted from cells and PCR was performed using HSV-1 specific primers. Preparation of the reaction mix was based on the protocol of HSV-1 diagnostic PCR kit (Dynamic BioScience). The DNA was amplified in a thermal cycler for 40 cycles. Before the first cycle, an early denaturation step of 3 min at $94{ }^{\circ} \mathrm{C}$ was performed to complete the dena-turation. Each cycle consisted of a $30 \mathrm{sec}$ denaturation step at 94 ${ }^{\circ} \mathrm{C}$, a $30 \mathrm{sec}$ annealing step at $50.5{ }^{\circ} \mathrm{C}$, and a $30 \mathrm{sec}$ elongation step at $72{ }^{\circ} \mathrm{C}$. After the last cycle, a final elongation step of $10 \mathrm{~min}$ at $72{ }^{\circ} \mathrm{C}$ was performed to complete the elongation. The samples were then kept at $4{ }^{\circ} \mathrm{C}$ until analysis. Amplified products were visualized under ultraviolet light after electrophoresis for $1 \mathrm{~h}$ at $100 \mathrm{~V}$ through a $1.5 \%(\mathrm{w} / \mathrm{v})$ agarose gel, containing ethidium bromide, and photographed. A molecular size marker included in the gel was GelPilot 100 bp plus ladder (QIAGEN).

\section{Results}

\section{Cytotoxicity}

Cytotoxicity of P.harmala seed extract was examined by means of trypan blue exclusion method. Microscopic observations showed that no change occurred in cell growth and morph-ology in the presence of extract up to a concentration of 667 $\mu \mathrm{g} / \mathrm{ml}$. Trypan blue exclusion method showed that the total viable cell numbers were approx-imately $98 \%$ as compare with the control cells (data not shown).

\section{Virus yield reduction assay}

The inhibition of virus yield by the extract was evaluated by TCID50 assay in Vero cells. We 


\section{Peganum harmala seed extract can prevent HSV-1 replication}

examined the antiviral activity of the extract when incubated with cells prior to infection with the virus; the virus titer of the supernatant did not show any signif-icant change in this case. To examine the direct effect of the extract to virus, HSV was mixed with nontoxic concentration of the extract and the mixture was used for infecting cells; the result of virus yield inhibition showed no distinct drop in virus titer.

In order to study the antiviral activity after viral adsorption, the extract was incubated with the infected cell monolayer $1,4,8$, and $12 \mathrm{~h}$ after infection. Results are shown in Fig.1. The most inhibitory effect of the extract was shown $1 \mathrm{~h}$ after infection, when the virus titer of the supernatant dropped from $10^{6.5} \mathrm{TCID} 50 / \mathrm{ml}$ to $10^{3.5} \mathrm{TCID} 50 / \mathrm{ml}$. Inhibitory effect of the extract was not significant in other cases, except for $4 \mathrm{~h}$ that reduced virus titer from $10^{6.5} \mathrm{TCID} 50 / \mathrm{ml}$ to $10^{4.5} \mathrm{TCID} 50 / \mathrm{ml}$.

As it is shown in fig.1, treating infec-ted cells $1 \mathrm{~h}$ after infection was not completely inhibited virus growth, but after third passage in presence of the extract, virus production was completely inhibited.

\section{Immunofluorescence}

To confirm the inhibitory effect of P. harmala seed extract on HSV-1 replication in cell culture, coverslip-grown Vero cells infected with HSV-1 in the presence and absence of the extract, were fixed and processed for indirect Immunofluorescent assay. The expre-ssion of HSV-1 proteins was evidenced after $16 \mathrm{~h}$ of infection in untreated group and its characteristic cytophatic effects were apparent.

Repeating the same experiment in the presence of the extract, expression of HSV-1 proteins became very weak and did not show significant fluorescence in $3^{\text {rd }}$ passage.

\section{Viral DNA synthesis}

To determine presence of viral DNA in extract of treated infected cells, DNA was extracted from cells and PCR test was performed using HSV-1 specific primers. Although viral DNA was detected at first passage, there was no detectable DNA after third passage.

\section{Discussion}

Human herpes viruses are found worldwide and are among the most frequent causes of viral infections in immunoincompetent as well as in immunocompromised patients (15). HSV infection is one of these infectious diseases, which occurs in far-ranging region of body. HSV-I mainly causes infection on the craniofacial skin and mucosa, and HSV-II results in the infection of genitals and anus. HSV induces a variety of diseases, for example, herpesencephalitis, herpetic keratitis, herpetic gingivitis, herpes genitalis, infection of newborn and fetal malformation, some of which are lethal (16). Currently, the primary drugs used for HSV infection are nucleoside analogues. Among these, acyclovir is the preferred medicine in clinical treatment, but the drug resistance develops after longterm administration (17). Meanwhile, the extracts of some medicinal herbs were investigated in term of searching hopeful candidates for treating HSV infection $(18,19)$.

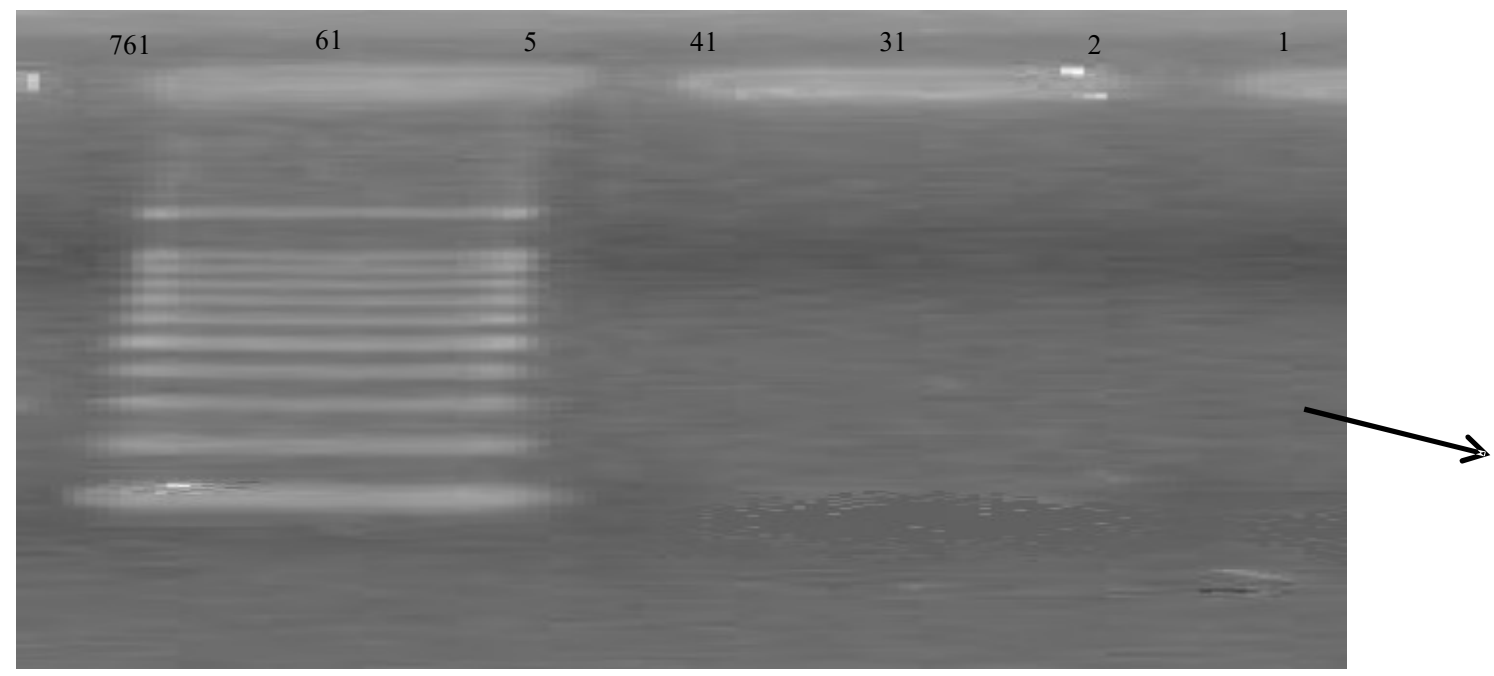

$296 \mathrm{bp}$

Fig. 3: Effect of the extract on viral DNA synthesis; Lane 1: HSV-1 positive control; Lane 2: MW Marker; Lane 3: first passage; Lane 4: second passage; Lane 5: third passage; Lane 6: negative control; Lane 7: MW Marker. 
Peganum harmala is a plant known since the first century A.D. and still, currently used for therapeutic purposes. Harmaline, the active principle of the plant seeds, and its derivatives, cause visual troubles, loss of coordination, agitation and delirium, and, at high doses, it can produce paralysis (20). The present study was initiated to evaluate inhibitory effect of the extract of $\mathrm{P}$. harmala on HSV-1 replication in vitro.

In this study, the effect of different concentrations of the extract on Vero cells was determined after $72 \mathrm{~h}$ incubation by Trypan blue exclusion method. P.harmala seed extract had no cytotoxicity on Vero cells up to concentration of $667 \mu \mathrm{g} / \mathrm{ml}$. The inhibition of virus yield showed that treating the cells with the extract $1 \mathrm{~h}$ after infection can significantly reduce virus titer in the first passage and inhibit completely virus production in the third passage. Regarding the HSV replication cycle, soon after infection, approximately 2 to 4 hours postinfec-tion (hpi), the $\alpha$ or immediate early (IE) genes are expressed. Although transcription of $\alpha$ genes requires no prior viral protein synthesis, an HSV protein brought in with the virion tegument, VP16, stimulates transcript-tion of $\alpha$ genes (21). Therefore, inhibitory effect of the extract $1 \mathrm{~h}$ after infection can be caused by preventing $\alpha$ genes protein synthesis or possibly repressing function VP16 tegument protein.

Evaluation of HSV-1 protein expres-sion in treated infected cells by Immunofluorescence assay showed significant reduction in protein synthesis at first passage and complete repression in third passage which means that the extract can prevent viral gene expression in transcription or translation level.

Finally, for investigating the effect of the extract on viral DNA synthesis, PCR test was performed on the supern-atant of three passages. Although there were detectable DNA bands in $1^{\text {st }}$ and $2^{\text {nd }}$ passages, we could not detect any DNA band in $3{ }^{\text {rd }}$ passage, indicating that viral DNA synthesis was completely inhibited in third passage. Regarding to this results, we can conclude that inhibitory effect of P.harmala seed extract is not clearly understood.

Further study is required to determine the mechanism of viral growth inhibition.

\section{References}

1. Field, A. K. and K. K.; 1994; Biron The end of innocerice revisited: resistance of herpesvirus to antiviral drugs. Clin icrobiol Rev 7:1-13.
2. Awadh-Ali, N. A., W. D. Julich, C. Kusnick and U. Lindequist; 2001; Screening of Yemeni medicinal plants for antibacterial and cytotoxic activities. Journal of Ethnopharmacology 74:173-179.

3. Zargari, A.; 1989; Medicinal Plants. Vol. 1, Tehran University Press, Tehran, pp 637-639.

4. Lamchouri, F., A. Settaf and Y. Cherrah; 1999; Antitumour principles from peganum harmala seeds. Therapie 54:753-758.

5. Kuhn, M. A. and D. Winston; 2000; Herbal therapy and supplements, a scientific and traditional approach. Lippincott, New York, pp 347-350.

6. Okigbo, R. N., C. L. Anuagasi and J. E. Amadi; 2009, Advances in selected medicinal and aromatic plants indigenous to Africa. Journal of Medicinal Plants Research 3(2):8695.

7. Abdel-Fattah, A. F. M., K. Matsumoto and Y. Murakami; 1997; Central serotonin leveldependent changes in body temperature following administration of tryptophan to pargyline- and harmaline- pretreated rats. Gen Pharmacol 28:405-409.

8. Saleem, A, M. Engstrom and S. Wurster; 2001; Intraction of folk medicinal plant with human $\alpha 2$-adrenoceptor subtypes. Med Plant Pakistan 57:332-338.

9. Saad, E. L. and M. Rifaie; 1980; Peganum harmala: its use in certain dermatoses. Int $\mathrm{J}$ Dermatol 19:221-222.

10. Abdel-Fattah, A. F. M., K. Matsumoto, H. A. K. Gammaz and H. Watanabe; 1995; Hypothermic effect of harmala alkaloid in rats: involvement of serotonergic mechanism. Pharmacol Biochem Behav 52:421-426.

11. Adams, S. M.; 1983; The antineoplasticeffects of prunusarmeniaca and peganum harmala. Diss Abstr Int (Sci) 44:1052-1055.

12. Reed, L. J. and H. A. Muench; 1932; Simple method for estimating 50\% endpoint. Am J Hygine 27:493-497.

13. Burlesson, F. G, T. M. Chambers and D. L. Wedbrauk; 1992; Cytopathic effect Inh. Bioassay. Virology. A Laboratory Manual. Academic Press, New York, pp 127-135.

14. Cinatl, J., U. Vogel, J. Cinatl, H. Kabickova, B. Kornhuber and H. W. Doerr; 1997; 
Antiviral effects of 6-diazo-5-oxo-L-norleucin on replication of Herpes Simplex Virus type-1. Antiviral Res 33:165-175.

15. Villarreal, E. C.; 2003; Current and potential therapies for the treatment of herpes-virus infections. Prog Drug Res 60:263.

16. Chen, H. Z.; 2001; Practice of internal medicine, 1lth Edition. Bcijing: People's Medical Publishing House, pp 356-357.

17. Whitley, R. J. and B. Roizman; 2001; Herpes simplex virus infections. Lancet 357 (9267):1513.

18. Guarino, C. and R. Sciarrillo; 2003; Inhibition of herpes simplex virus type 1 by aqueous extracts from leaves of Helichrysum litoreum Guss. Boll Chim Farm 142 (6):242.

19. Yoosook, C., N. Bunyapraphatsara, Y. Boonyakiat and C. Kantasuk; 2000; Antiherpes simplex virus activities of crude water extracts of Thai medicinal plants. Phytomedicine 6:411-419.

20. Lamchouri, F., A. Settaf, Y. Cherrah, M. ElHamidi, N. Tligui, B. Lyoussi and M. Hassar; 2002; Experimental toxicity of Peganum harmala seeds. Ann Pharm Fr 60(2):123-129.

21. Knipe, D. M. and P. M. Howley; 2007; Fields Virology. 5th ed. Lippincott Williams \& Wilkins, Philadelphia. 